\title{
Identifikasi Potensi Desa Wisata di Kecamatan Jerowaru, Kabupaten Lombok Timur
}

\author{
Lalu Adi Permadi', Thatok Asmony², Harmi Widiana ${ }^{3}$, Hilmiati $^{4}$ \\ 1,2,3,4 FEB Universitas Mataram \\ lombokconference@unram.ac.id
}

\begin{abstract}
This research aimed to identify potential tourism village in the District of Jerowaru, East Lombok Regency. The data used were the primary and secondary data. Primary data obtained by interviews, while secondary data obtained from literature related studies, websites, data and information from the local government. The study analysis were included an analysis for the tourism potential in the village and an analysis for the possiblility development of tourist villages in the district. The study found that the potential development of tourist villages in the district was spreading. The identification result showed there were 6 villages that possible for tourist village in district of Jerowaru. The villages were classified into two categories namely the village ready to be a tourism village and pre-release tour village. The villages that ready to be a tourism village in Jerowaru are Sekaroh and Ekas Buana.
\end{abstract}

Key words: potential, development, tourism village, East Lombok, Jerowaru 


\section{Pendahuluan}

Pariwisata merupakan industri yang sangat makro dan dinamis. Wisatawan sebagai konsumen dari pariwisata juga sangat dinamis. Mereka mulai beralih kepada produk wisata yang lebih menghargai agama, lingkungan, alam, budaya dan atraksi secara spesial. Wisatawan tidak hanya tertarik pada keindahan alam dan kelengkapan fasilitas wisata melainkan juga pada kesesuaian dengan agama mereka, keleluasaan dan intensitas interaksi dengan lingkungan dan masyarakat lokal.

Salah satu pendekatan pengembangan wisata alternatif adalah desa wisata. Produk ini yang membuat para wisatawan dekat dengan suasana dan penduduk lokal. Ramuan utama desa wisata diwujudkan dalam gaya hidup dan kualitas hidup masya-rakatnya. Keaslian juga dipengaruhi keadaan ekonomi, fisik dan sosial daerah pedesaan tersebut, misalnya ruang, warisan budaya, kegiatan pertanian, bentangan alam, jasa, pariwisata sejarah dan budaya, serta pengalaman yang unik dan eksotis khas daerah. Untuk itu pemodelan desa wisata harus terus dan secara kreatif mengembangkan identitas atau ciri khas daerah (Sastrayuda, 2010).

Nuryanti (1993) dalam Soemarno (2010) menyatakan bahwa Desa wisata merupakan suatu bentuk integrasi antara atraksi, akomodasi dan fasilitas pendukung yang disajikan dalam suatu struktur kehidupan masyarakat yang menyatu dengan tata cara dan tradisi yang berlaku.

Provinsi Nusa Tenggara Barat (NTB) mempunyai potensi budaya dan alam yang memungkinkan pertumbuhan dan pengembangan wilayahnya yang berbasis pada pariwisata. Tercatat dua desa wisata yang terkenal di NTB yaitu Desa Wisata Sukarara dan Desa Wisata Rambitan khususnya Dusun Sade. Kedua desa wisata ini terletak di Kabupaten Lombok Tengah. Sementara itu Lombok Timur juga memiliki desa wisata Sembalun Bumbung dan Sembalun Lawang di Kecamatan Sembalun yang begitu luas di lembah timur Gunung Rinjani.

Selain Sembalun dan Gili Lampu, Lombok Timur masih memiliki sejumlah keunikan dan keaslian yaitu pantai-pantai di wilayah selatan yang terdiri dari dua kecamatan yaitu Kecamatan Jerowaru dan Kecamatan Keruak. Kedua kecamatan ini memiliki pantai yang indah dan alami. Jerowaru misalnya memiliki pantai yang bernama Pantai Pink yang memiliki pasir putih kemerahan. Namun perkembangan pariwisata Jerowaru belum maksimal. Hal ini terlihat dengan minimnya jaringan akomodasi internasional dan nasional yang masuk untuk membangun hotel di wilayah selatan tersebut.

Melihat gambaran tersebut, sangat memungkinkan untuk mengembangkan dan memasarkan desa wisata sebagai produk wisata Jerowaru yang memberikan keuntungan untuk para pelaku wisata tetapi juga dapat meningkatkan ekonomi masyarakat secara keseluruhan. Untuk mengem-bangkan produk desa wisata di Jerowaru, maka perlu dilakukan identifikasi potensi desa wisata di kecamatan tersebut. Dari studi tersebut diharapkan dapat diidentifi-kasi desa-desa yang potensial menjadi desa wisata di Jerowaru serta faktor internal pendukung pengembangan desa-desa tersebut untuk menjadi desa wisata yang layak untuk dipasarkan. Dengan demikian pengembangan dan pembangunan desa wisata di Jerowaru dapat difokuskan di desa-desa yang potensial untuk pari-wisata.

\section{Metode}

Berdasarkan tema di depan, maka desain yang dipergunakan dalam penelitian ini akan bersandarkan pada pendekatan kualitatif. Dengan pendeka- 
tan ini, kiranya berbagai aspek yang diteliti akan dapat menghasilkan data yang valid, reliabel, dan relevan dengan yang didibutuhkan nantinya. Selain itu, dengan pendekatan kualitatif akan dapat dilakukan observasi yang lebih mendalam dan teliti terhadap objek-objek penelitian, sehingga data-data yang diperoleh lebih akurat dan mendasar.

Berdasarkan tujuan dari studi ini, yaitu menemukenali potensi desa wisata di Kecamatan Jerowaru Kabupaten Lombok Timur, maka pendekatan dalam penelitian ini adalah pendekatan PASOLP (Product Analysis Sequence for Outdoor Leisure Procedure). Pendekatan PASOLP sendiri merupakan pendekatan perencanaan kawasan wisata modern yang menyertakan antara kebijakan nasional/ daerah, lingkungan dan sektor ekonomi yang terkait dengan perencanaan (Gunardi, 2010).

Dalam penelitian ini penulis membatasi penelitian sampai dengan tahap rekomendasi kebutuhan dan prioritas, sesuai dengan tujuan dari penelitian ini.

Dalam penelitian ini analisis yang dilakukan terhadap data sekunder menjadi pendukung bagi analisis data primer atas survey lapangan dan wawancara. Analisis data primer dilakukan untuk menggambarkan kondisi kawasan studi baik permasalahan maupun potensi yang ada sehingga dapat ditemukan faktor-faktor yang dapat menunjang potensi wisata di kawasan ini. Peneliti selanjutnya meng-gunakan kategori desa wisata menurut oleh Permadi dkk (2017) untuk meng-klasifikasi tingkat kesiapan desa wisata potensial yang ada di Kecamatan Jerowaru. Permadi dkk (2017) mengklasifikasikan desa wisata potensial menjadi tiga kategori yaitu kategori Desa Wisata Paripurna (Desa wisata yang betul-betul siap memenuhi semua syarat desa wisata), kategori Desa Wisata Permulaan (Desa wisata yang memenuhi syarat sebagian dari syarat desa wisata), dan Kategori terendah adalah Rintisan Desa Wisata (Desa potensial namun belum memenuhi sebagian besar dari syarat desa wisata).

Studi ini dilaksanakan di pedesaan Kecamatan Jerowaru Kabupaten Lombok Lombok Timur (sebagai fokus penelitian). Penelitian ini akan menggunakan tokoh pemerintah dan masyarakat sebagai informan penelitian. Jumlah informan yang direncanakan adalah sebanyak 50 orang.

Instrumen utama dalam penelitian yang mempergunakan metode kualitatif adalah peneliti sendiri. Peneliti langsung turun ke lapangan, melakukan observasi ke lapangan dan wawancara dengan para informan. Alat bantu peneliti adalah tape recorder, buku catatan, dan kamera photo digital.

Data yang terkumpul melalui hasil observasi, wawancara, dan dokumentasi ini berupa data kualitatif. Teknik yang dipergunakan untuk menganalisis data penelitian adalah teknik analisis deskriptif interpretatif dengan langkah-langkah sebagai berikut: (1) Memilih dokumen /data yang relevan dan memberi kode. (2) Membuat catatan objektif, (3) Membuat catatan reflektif, yaitu menuliskan apa yang sedang dipikirkan peneliti sebagai interpretasi dalam sangkut pautnya dengan catatan objektif. (4) Menyimpulkan data. (5) Melakukan triangulasi yaitu mengecek kebenaran data dengan cara menyimpulkan data ganda.

\section{Hasil dan Pembahasan \\ Analisis Potensi Desa Wisata}

Kabupaten Lombok Timur adalah kabupaten di Pulau Lombok terletak pada $116^{\circ}-117^{\circ}$ Bujur Timur dan $8^{\circ}-9^{\circ}$ Lintang Selatan. Luas wilayah Kabupaten Lombok Timur $2.679,99 \mathrm{~km} 2$ yang terdiri dari daratan seluas 1.605,55 km2 (59,91\% luas Lombok Timur) dan lautan seluas 1.074,33 km2 (40,09 \% luas Lombok Timur). Dengan batas wilayah di Sebelah Barat: Kab. Lombok 
Utara dan Lombok Tengah; di Sebelah Timur : Selat Alas; di Sebelah Utara : Laut Jawa; dan Sebelah Selatan : Samudera Indonesia.

Luas daratan Kabupaten Lombok Timur mencakup 7,97 persen dari luas daratan Provinsi Nusa Tenggara Barat. Ketinggian topografi di Kabupaten Lombok Timur Cukup bervariasi mulai dari o meter di atas permukaan laut (mdpl) yang merupakan dataran pantai dibagian selatan Kabupaten Lombok Timur hingga 3.775 mdpl yang berupa areal pegunungan (kompleks Rinjani) di bagian utaranya.

Pemerintah Kabupaten Lombok Timur menyadari bahwa pariwisata itu sangat penting untuk mendukung pembangunan ekonomi daerahnya. Pemerintah Kabupaten membagi destinasi atau fokus tujuan wisata yang dibina menjadi Wisata Alam, Wisata Pantai, Wisata Budaya, Wisata Kerajinan, Wisata Seni, Wisata Atraksi, dan Wisata Tirta. Selain itu pemerintah Kabupaten Lombok Timur juga menerapkan beberapa kebijakan berikut ini. Pertama, mengembangkan pariwisata cagar budaya; kedua, mendukung wisata kuliner dan Ketiga, secara rutin menyeleng-garakan event atau acara baik acara yang waktunya bulanan ataupun tahunan

Salah satu kecamatan yang memungkinkan untuk pariwisata alam maupun budaya adalah Kecamatan Jerowaru yang terletak di ujung Selatan Lombok Timur. Kecamatan ini memiliki luas wilayah sekitar 142,78 Km². Menurut data BPS 2015 penduduk Kecamatan Jerowaru berjumlah 58.069 jiwa dengan tingkat kepadatan 407 orang per km persegi. Kecamatan ini berbatasan dengan Kabupaten Lombok Tengah di Barat dan Kecamatan Keruak di utara.

Di Kecamatan Jerowaru menurut data dari Bappeda Prov. NTB 2015 terdapat 15 Desa. Jumlah ini berkembang dari empat Desa di akhir tahun 2003.
Tabel 1. Desa-desa di Jerowaru

\begin{tabular}{|r|l|}
\hline No & Desa \\
\hline 1 & JEROWARU \\
\hline 2 & WAKAN \\
\hline 3 & PANDAN WANGI \\
\hline 4 & SEKAROH \\
\hline 5 & PEMONGKONG \\
\hline 6 & SUKARAJA \\
\hline 7 & EKAS BUANA \\
\hline 8 & SERIWE \\
\hline 9 & SEPAPAN \\
\hline 10 & BATU NAMPAR \\
\hline 11 & PAREMAS \\
\hline 12 & KWANG RUNDUN \\
\hline 13 & SUKADAMAI \\
\hline 14 & BATU NAMPAR SELATAN \\
\hline 15 & PENE \\
\hline
\end{tabular}

Sumber: Nusa Tenggara Barat Dalam Data Tahun 2015

Kecamatan Jerowaru memiliki kekayaan potensi pengembangan budidaya perikanan pantai (Kerapu dan Lobster). Selain itu kecamatan ini menyimpan sejuta pesona pariwisata yang eksotis (Pantai Surga, Sungkun, Kaliantan, Cemara, Gili Sunut dan Tanjung Ringgit).

Di daerah selatan pulau Lombok termasuk Jerowaru, kekeringan dan kekurangan air bersih merupakan masalah klasik yang telah lama dihadapi oleh warga. Sampai saat ini masih banyak penduduk di kecamatan tersebut yang rata-rata hidup di bawah garis kemiskinan.

Secara umum mata pencaharian penduduk adalah bertani, berladang dan beternak. Pada musim hujan para petani menanam padi tadah hujan dengan sistem Gora (gogo rancah). Di musim kemarau sebagian menanam tembakau Virginia. Sebagian petani tembakau di Jerowaru dibina oleh perusahaan kemitraan seperti Sadana dan Djarum. Untuk menopang usaha pertanian ini para petani umumnya membangun semacam penampung air 
berukuran 0,5 - 2 hektare yang disebut Embung yang menampung air hujan di musim penghujan untuk digunakan mengairi sawah di musim kemarau.

Jerowaru juga dikenal sebagai sentra budidaya perikanan air tawar di embung-embung yang banyak tersebar terutama di Desa Sukaraja, Desa Jerowaru, Desa Pandan Wangi dan Desa Wakan. Jenis ikan yang dipelihara biasanya adalah ikan karper dan ikan nila, yang dipanen (biasanya dengan sistem memancing borongan) mulai bulan Mei sampai Agustus tiap tahunnya (Murdi, 2012).

\section{Idenfikasi Potensi Desa Wisata}

Potensi desa wisata di Jerowaru Lombok timur diidentifikasi dengan mengevaluasi syarat-syarat desa wisata sebagai berikut 1) Keunikan dan keaslian, 2) Letak dan aksesibilitas, 3) Budaya yang mencakup adat istiadat dan pelaku adat lokal serta norma setempat, 4) Sarana dan prasarana pendukung, 5) Alam, 6) Partisipasi masyarakat lokal, 7) Terjaminnya keamanan, ketertiban, dan kebersihan. Berikut ini hasil identifikasi desa wisata di Jerowaru Lombok Timur yang dilakukan tim peneliti.

\section{1) Keunikan dan Keaslian dari segi Alam, Sosial Budaya dan Industri}

Di dalam membahas keunikan dan keaslian desa Wisata di Jerowaru Lombok Timur, penulis menekankan pada ciri khas masing-masing desa wisata yang terdiri dari alam, sosial budaya dan industri di desa tersebut. Berikut hasil identifikasi terhadap keunikan desa-desa yang memiliki potensi menjadi desa wisata di Jeroawaru Lombok Timur.

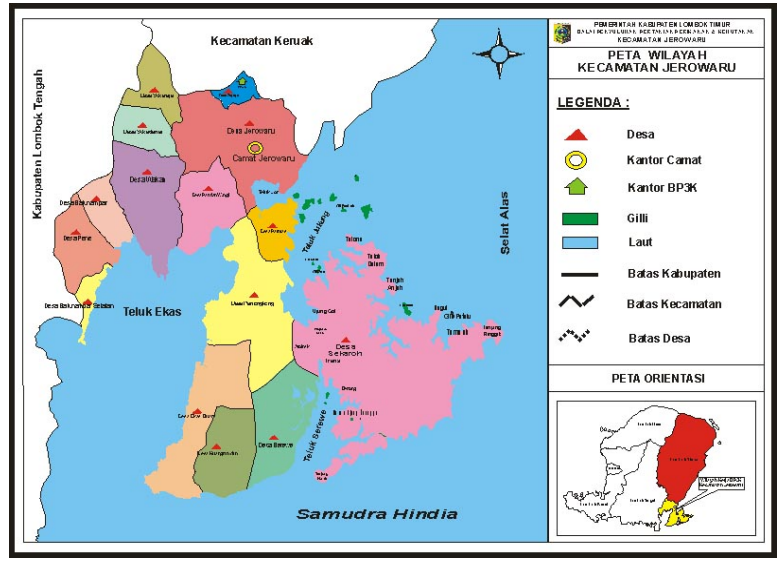

Gambar 1. Peta Wilayah Kecamatan Jerowaru

Secara umum kecamatan di Jerowaru memiliki kesamaan budaya yang berasal dari budaya Suku Sasak misalnya seperti ritual Bebubus Mangkung (semacam ritual pengobatan), ritual bau nyale atau cacing laut untuk desa pesisir selatan dan awig-awig atau hukum adat yang berlaku setempat.

Selain itu rata-rata desa-desa pantai di Kecamatan Jerowaru memiliki kesamaan fisik pantai yaitu memiliki pasir putih dan berbukit-bukit dengan tebing yang terjal. Pengecualian untuk Pantai Pink di Sekaroh yang memiliki pasir berwarna merah muda.

Dari hasil identifikasi keunikan desa-desa di Jerowaru diketahui bahwa ada sejumlah atraksi budaya yang dapat mendukung atraksi utama di desa-desa pantai tersebut. Misalnya di desa Ekas Buana terdapat ciri khas sebagai desa nelayan dan pondok apung tempat penangkaran ikan dan udang. Kegiatan nelayan dapat menjadi tontonan yang menarik bagi wisatawan terutama yang berasal dari kota besar seperti Jakarta.

Desa lain yang potensial dan unik adalah Desa Sekaroh. Dari identifikasi di lapangan ternyata desa tersebut tidak sekedar memiliki potensi pariwisata alam tetapi juga mempunyai pariwisata industri seperti perikanan. Tidak hanya itu Sekaroh memiliki lokasi menarik Tanjung Bloam 
yang menjadi tempat konservasi penyu.

Desa Batu Nampar yang terkenal dengan lokasi pemancingan laut mempunyai potensi wisata sejarah. Menurut hasil penelitian Murdi (2012) di Jerowaru pernah berdiri sebuah kerajaan yaitu Kera- jaan Pena. Kerajaan tersebut awalnya berpusat di bukit Pena, desa Batu Nampar Jerowaru. Penyebaran agama Islam dan perpaduannya dengan adat istiadat di daerah kering itu tidak terlepas dari peranan kerajaan kecil tersebut (Murdi, 2012).

Tabel 2. Keunikan dan keaslian Desa Wisata di Kecamatan Jerowaru

\begin{tabular}{|c|c|c|}
\hline No & Desa & Keunikan/Ciri khas \\
\hline 1 & KWANG RUNDUN & $\begin{array}{l}\text { Pantai Kura-kura atau Pantai Sungkun adalah lokasi penangkapan nyale (semacam } \\
\text { cacing laut) }\end{array}$ \\
\hline 2 & BATU NAMPAR & $\begin{array}{l}\text { Pantai Batu Nampar ini masih alami, karena relatif belum banyak aktivitas pem- } \\
\text { bangunan dan pengelolaan di pesisirnya. Wisata Kuliner Lobster, Gili Linus, di ba- } \\
\text { gian timur Pantai Batu Nampar terdapat bukit-bukit yang eksotis, terdapat } \\
\text { kearifan lokal berupa awig-awig atau hukum adat tidak tertulis yang mengatur pe- } \\
\text { nangkapan udang, kawasan pemancingan laut (Suntalangu, 2015) }\end{array}$ \\
\hline 3 & EKAS BUANA & $\begin{array}{l}\text { Pantai Surga, erat dengan aktivitas para nelayan. Terdapat sekitar } 50 \text { pondok } \\
\text { apung dengan sampan yang bersandar di sampingnya. Pondok apung tersebut } \\
\text { dibuat oleh para nelayan untuk menangkarkan Ikan Kerapu dan udang. } \\
\text { Wisatawan juga bisa mengikuti aktivitas para nelayan ketika berada di darat. Sep- } \\
\text { erti bagaimana mereka membuat perahu dan sampan dengan peralatan yang se- } \\
\text { derhana. Di "Berugak" (semacam gubug atau gazebo) Wisatawan bisa melihat } \\
\text { proses pemotongan ikan. Ikan-ikan yang dipotong tersebut kemudian dipakai un- } \\
\text { tuk memberi makan Ikan Kerapu yang ada di pondok apung (Panca, 2017) }\end{array}$ \\
\hline 4 & PEMONGKONG & $\begin{array}{l}\text { Salah satu Produsen Garam terbesar di Lombok Timur dengan produksi 4.908,30 } \\
\text { ton di tahun 2012, Lokasi industri terasi, penangkapan rajungan (Nurlaili, Cornelia, } \\
\text { \& Zamron, 2014). Terdapat wisata alam Tanjung Perak dan Tanjung Cina, }\end{array}$ \\
\hline 5 & SEKAROH & $\begin{array}{l}\text { Gili Sunut (Sebuah pulau eksotis), Pantai Pink (Pantai ini merupakan salah satu dari } \\
\text { tujuh pantai di dunia yang memiliki pasir pantai berwarna pink, dan satu dari dua } \\
\text { pantai di Indonesia yang memiliki pasir pantai berwarna pink), Tanjung Ringgit } \\
\text { (dapat melihat sunset dan sunrise), Tanjung Bloam (daerah konservasi penyu), } \\
\text { gua peninggalan Jepang di bukit sisi tengah Pantai Pink (Rijal, 2017) }\end{array}$ \\
\hline 6 & SERIWE & $\begin{array}{l}\text { Tanjung Ringgit, Pantai Kaliantan, Pantai Cemara, acara bau nyale/acara me- } \\
\text { nangkap cacing laut, kondisi fisik kawasan pantai yang memiliki ciri khas antara lain } \\
\text { : Jenis material pasir yang warna dan bentuknya menyerupai merica, serta terum- } \\
\text { bu karang yang masih menampakkan kelestariaanya sehingga menjadi obyek bagi } \\
\text { kegiatan Snorkling dan gelombang laut yang cukup memadai untuk berselancar } \\
\text { (Syarief, 2014) }\end{array}$ \\
\hline
\end{tabular}

\section{2) Objek Wisata Sekitar dan Atraksi Pa- riwisata Utama}

Dari hasil wawancara dan penelurusan data sekunder yang telah dilakukan, diketahui bahwa terdapat enam desa di Jerowaru yang diduga berpotensi menjadi desa wisata. Dalam Tabel 2 berikut ini dipaparkan desa beserta objek wisata terdekat dan atraksi utama dari masing-masing desa tersebut.

Di Kecamatan Jerowaru terdapat sekitar sepuluh objek wisata yang letaknya relatif berdekatan. Kondisi banyaknya objek wisata di Kecamatan Jerowaru tersebut tentunya menguntungkan bagi pengembangan desa wisata. Wisatawan yang berkunjung ke Sekaroh misalnya selain ke Pantai Pink yang sering juga disebut Pantai Tangsi, dapat juga berkunjung ke Gili Sunut, Tanjung Ringgit dan Pantai Cemara. 
Tabel 3 Objek Wisata dan Atraksi Utama Pariwisata sekitar Desa Wisata di Kecamatan Jerowaru, Lombok Timur

\begin{tabular}{|l|l|l|l|}
\hline No & \multicolumn{1}{|c|}{ Desa } & Objek Wisata Terdekat & \multicolumn{1}{|c|}{$\begin{array}{c}\text { Atraksi } \\
\text { Utama }\end{array}$} \\
\hline 1 & $\begin{array}{l}\text { KWANG } \\
\text { RUNDUN }\end{array}$ & $\begin{array}{l}\text { Pantai Surga } \\
\text { Pantai Sungkun } \\
\text { Pantai Kaliantan } \\
\text { Pantai Cemara }\end{array}$ & $\begin{array}{l}\text { Alam Pan- } \\
\text { tai }\end{array}$ \\
\cline { 1 - 2 } 2 & BATU NAMPAR & \\
\cline { 1 - 2 } 3 & EKAS BUANA & $\begin{array}{l}\text { Pantai Pink, } \\
\text { Cili Sunut, } \\
\text { Tanjung Ringgit, } \\
\text { Tanjung Perak, } \\
\text { Pantai Ekas } \\
\text { Pantai Tanjung Bloam }\end{array}$ & \\
\hline 5 & PEMONGKONG & SEKAROH & \\
\hline 6 & SERIWE & \multicolumn{2}{|l}{} \\
\hline
\end{tabular}

Tabel 4. Letak dan Aksesibilitas

\begin{tabular}{|l|l|l|l|l|}
\hline No & \multicolumn{1}{|c|}{ Desa } & \multicolumn{1}{|c|}{ Kondisi Akses Jalan } & \multicolumn{1}{|c|}{$\begin{array}{c}\text { Jarak dari } \\
\text { lbu Kota } \\
\text { Provinsi }\end{array}$} & $\begin{array}{l}\text { Jarak dari lbu Ko- } \\
\text { ta Kabupaten }\end{array}$ \\
\hline 1 & KWANG RUNDUN & $\begin{array}{l}\text { Jalan raya Hotmix via By Pass } \\
\text { BIL }\end{array}$ & $77,8 \mathrm{~km}$ & $39,6 \mathrm{~km}$ \\
\hline 2 & BATU NAMPAR & Jalan raya Hotmix & $58,4 \mathrm{~km}$ & $35,4 \mathrm{~km}$ \\
\hline 3 & EKAS BUANA & Jalan raya Hotmix & $75,3 \mathrm{~km}$ & $37,1 \mathrm{~km}$ \\
\hline 4 & PEMONGKONG & $\begin{array}{l}\text { Jalan raya Hotmix. Untuk ke Gili } \\
\text { Sunut tersedia perahu motor. }\end{array}$ & $73,1 \mathrm{~km}$ & $34,9 \mathrm{~km}$ \\
\hline 5 & SEKAROH & $\begin{array}{l}\text { Jalan raya Hotmix dan tanah } \\
\text { (dalam kondisi rusak) }\end{array}$ & $78,5 \mathrm{~km}$ & $40,3 \mathrm{~km}$ \\
\hline 6 & SERIWE & Jalan raya Hotmix & $79,1 \mathrm{~km}$ & $40,9 \mathrm{~km}$ \\
\hline
\end{tabular}

\section{3) Letak dan aksesibilitas}

Letak Kecamatan Jerowaru yang cukup jauh dari ibukota Provinsi NTB Mataram sekitar 58 kilometer. Desa di Jerowaru yang paling mudah dijangkau dari kota Mataram adalah Batu Nampar. Namun letak dari dari arah Bandara Internasional Lombok kecamatan ini dapat dijangkau dengan perjalanan 1 jam.

Untuk akses jalan menuju ke obyek wisata di Kecamatan Jerowaru khususnya di Desa Sekaroh belum begitu bagus. Selain itu jalan di kecamatan di selatan Lombok Timur itu baru terkena banjir yang terjadi di akhir 2017.

Salah satunya obyek wisata di Desa
Sekaroh Kecamatan Jerowaru yaitu Gili Sunut. Hanya saja, kondisi jalan menuju Gili Sunut masih memprihatinkan. Sekitar 2 kilometer mendekati lokasi gili ini masih berupa jalan tanah. Pada musim penghujan, kondisi fisik jalannya pun menjadi licin dan sulit dilewati. Wisatawan dianjurkan berkunjung ke obyek tersebut sebelum musim penghujan turun (Anonim, 2017). 


\section{4) Sarana Utama dan Sarana Pen- dukung}

Dari identifikasi terhadap Sarana Wisata pada desa potensial menjadi desa wisata di Jerowaru, diketahui bahwa hampir sebagian besar desa tidak memiliki sarana utama yaitu akomodasi. Namun sebagian besar desa di kecamatan itu memiliki fasilitas pendukung seperti café dan restoran dan rekreasi pantai.

Desa-desa yang memiliki fasilitas akomodasi adalah Desa Kwang Rundung, Desa Ekas Buana dan Desa Sekaroh. Desa Kwang Rundun memiliki Resort Hotel yaitu Heaven on The Planet Resort dan Ekas Sunrise. Di Desa Kwang Rundun juga terdapat Homestay yaitu Villa Surf.

Tabel 5. Sarana dan prasarana pendukung Desa Wisata

\begin{tabular}{|c|c|c|c|}
\hline No & Desa & Sarana Utama & $\begin{array}{c}\text { Sarana } \\
\text { Penunjang }\end{array}$ \\
\hline 1 & KWANG RUNDUN & $\begin{array}{l}\text { Hotel dan Homestay: } \\
\text { Heaven on The Planet Re- } \\
\text { sort, Villa Surf, Ekas Sunrise }\end{array}$ & restoran, rekreasi pantai \\
\hline 2 & BATU NAMPAR & & $\begin{array}{l}\text { Café/restoran,rekreasi } \\
\text { pantai }\end{array}$ \\
\hline 3 & EKAS BUANA & $\begin{array}{l}\text { Hotel dan Homestay : Ekas } \\
\text { Breaks, Sunset Homestay }\end{array}$ & restoran, rekreasi pantai \\
\hline 4 & PEMONGKONG & & restoran, rekreasi pantai \\
\hline 5 & SEKAROH & $\begin{array}{l}\text { Hotel : Jeeva Beloam } \\
\text { Beach Camp }\end{array}$ & restoran, rekreasi pantai \\
\hline 6 & SERIWE & - & rekreasi pantai \\
\hline
\end{tabular}

\section{Partisipasi Masyarakat Lokal}

Partisipasi masyarakat di Jerowaru saat ini dalam pariwisata masih rendah. Kelompok sadar wisata di Kecamatan Jerowaru sudah terbentuk yaitu di Desa Ekas Buana dan Desa Sekaroh. Namun karena kurangnya pengetahuan tentang tujuan dan fungsi serta pengelolaan komunitas kelompok sadar wisata ini, keberadaannya saat ini tidak begitu aktif dan peranannya dalam memberikan pemahaman kesadaran wisata pada masyarakat masih rendah (Lutpi, 2016).

Peran masyarakat untuk membangun industri pariwisata termasuk akomodasi dan transportasi wisatawan belum signifikan. Rendahnya partisipasi masyarakat ini dikonfirmasi oleh Zulkarnaen, seorang pemandu wisata. Zulkarnaen menyatakan bahwa masyarakat Jerowaru sebagian besar masih kurang peduli pada pariwisata, mereka lebih peduli pada kegiatan lain seperti perikanan. Zulkarnaen yang biasa dipanggil Naen ini menerangkan bahwa masyarakat lebih senang dengan mengolah hasil alam seperti mengolah ikan dan udang menjadi terasi (Wawancara dengan Zulkarnaen, Mei 2017).

Pendapat Zulkarnaen sejalan dengan hasil penelitian Lutpi (2016) yang menemukan tingkat partisipasi masyarakat dalam pengembangan pariwisata pantai di Kecamatan Jerowaru masih rendah, ini terlihat dari empat indikator yaitu 1) partisipasi dalam perencanaan, 2) partisipasi dalam pelaksanaan, 3) partisipasi dalam pemanfaatan dan partisipasi dalam evaluasi.

Namun saat ini sudah ada kemajuan di desa-desa di Jerowaru. Hal tersebut terlihat dengan munculnya keinginan untuk mempromosikan pari-wisata desa. 
Terbukti dari penelurusan yang dilakukan penulis, terdapat empat desa membuat blog secara swadaya. Selain itu terdapat puluhan blog yang turut mempromosikan wisata di Jerowaru. Banyak juga situs internet yang mencoba meraih keuntungan dengan turut menggunakan Jerowaru sebagai konten situs mereka. Salah satunya www.dilombok.com/pantai-pinklombok/77/ yang menempatkan Pantai Pink di laman mereka.

Tabel 6. Partisipasi Masyarakat Lokal

\begin{tabular}{|c|c|c|c|c|}
\hline $\begin{array}{l}\mathrm{N} \\
\mathrm{O}\end{array}$ & Desa & $\begin{array}{l}\text { PokDar- } \\
\text { Wis }\end{array}$ & Website/Blog Desa & $\begin{array}{l}\text { Peranserta Masyarakat } \\
\text { desa }\end{array}$ \\
\hline 1 & KWANG RUNDUN & & $\begin{array}{l}\text { de- } \\
\text { sakwangrundun.blogspot.co.i } \\
\text { d }\end{array}$ & $\begin{array}{l}\text { Mempromosikan lewat } \\
\text { blog }\end{array}$ \\
\hline 2 & BATU NAMPAR & & & - \\
\hline 3 & EKAS BUANA & $\begin{array}{l}1 \mathrm{Ke}- \\
\text { lompok }\end{array}$ & $\begin{array}{l}\text { objekwisatajero- } \\
\text { waru.blogspot.co.id }\end{array}$ & $\begin{array}{l}\text { Desa aktif berpartisipasi } \\
\text { membangun pariwisata }\end{array}$ \\
\hline 4 & PEMONGKONG & & $\begin{array}{l}\text { desape- } \\
\text { mongkong.blogspot.co.id }\end{array}$ & $\begin{array}{l}\text { Mempromosikan lewat } \\
\text { blog }\end{array}$ \\
\hline 5 & SEKAROH & $\begin{array}{l}1 \mathrm{Ke}- \\
\text { lompok }\end{array}$ & $\begin{array}{l}\text { wisatalomboktimurjero- } \\
\text { waru.blogspot.co.id }\end{array}$ & $\begin{array}{l}\text { Desa aktif berpartisipasi } \\
\text { membangun pariwisata }\end{array}$ \\
\hline 6 & SERIWE & & & - \\
\hline
\end{tabular}

\section{Analisis Pengembangan Produk Kawasan Desa Wisata}

Dari Hasil identifikasi potensi desa wisata di Jerowaru maka dapat dilakukan sejumlah pengembangan produk wisata. Pengembangan produk ini sesuai dengan kondisi dan potensi masing-masing desa. Pengembangan produk dari kawasan desa wisata di Jerowaru dapat dilakukan dengan beberapa cara mengembangkan yaitu jasa akomodasi, jasa pemandu wisata, rekreasi, hiburan untuk wisatawan berbasis budaya, produk wisata partisipatif seperti pelatihan keterampilan bagi wisatawan dan produk kuliner khas daerah

\section{Analisis Stakeholders}

Dalam kasus perencanaan pengembangan desa wisata di Jerowaru, pemerintah pusat, pemerintah Provinsi NTB, pemerintah kabupaten Lombok Timur, pemerintah Kecamatan Jerowaru 4. kelemahan, peluang dan tantangan desa wisata. Dengan demikian pemangku kepentingan seperti pemerintah dan pengusaha, wisatawan dan masyarakat desa memiliki peran yang lebih spesifik. Ini mengingat tantangan yang berbeda di Lombok Timur. Meskipun peran tersebut spesifik namun dapat dikolaborasikan. Para stakeholder ini dalam perencanaan dan kelangsungan desa wisata di Jerowaru Lombok Timur dapat berperan secara kolaboratif dengan melakukan beberapa hal berikut ini.

1. Perencanaan Desa Wisata berdasarkan analisis kekuatan, kelemahan, peluang dan tantangan desa wisata.

2. Melakukan kegiatan pemasaran desa wisata di wilayah Jerowaru baik itu secara sederhana maupun secara komprehensif. Yang dimaksud pemasaran desa wisata secara sederhana adalah mempromosikan desa wisata dengan menyebarkan keistimewaan produk desa tersebut dari mulut ke mulut.

3. Memberi input bagi pemangku kepentingan yang lain tentang kekuatan, pengusaha dapat membuat strategi yang lebih baik. 


\section{Pembahasan}

Tabel 7. Hasil Identifikasi Desa yang memenuhi Syarat Menjadi Desa Wisata di Kec. Jerowaru Lombok Timur

\begin{tabular}{|l|l|l|}
\hline No & Desa & $\begin{array}{l}\text { Syarat yang } \\
\text { terpenuhi }\end{array}$ \\
\hline 1 & KWANG RUNDUN & $1,2,3,4,5$, \\
\hline 2 & BATU NAMPAR & $1,2,3,5$ \\
\hline 3 & EKAS BUANA & $1,2,3,4,5,6$ \\
\hline 4 & PEMONGKONG & $1,2,3,5,6$ \\
\hline 5 & SEKAROH & $1,2,3,4,5,6$ \\
\hline 6 & SERIWE & $1,2,3,5$ \\
\hline
\end{tabular}

Dari tabel 7 diketahui bahwa desa yang paling siap untuk dikembangan menjadi desa wisata adalah Desa Ekas Buana dan Desa Sekaroh. Di kedua desa ini ke tujuh syarat desa wisata hampir semua terpenuhi kecuali syarat ke tujuh. Yang paling mendukung adalah keberadaan hotel bertaraf internasional sebagai sarana utama pariwisata yang harus terpenuhi. Syarat ini yang tidak dimiliki oleh desa-desa lain di wilayah Jerowaru.

Hal yang istimewa dari identifikasi yang dilakukan di wilayah pedesaan Jerowaru Lombok Timur adalah hampir semua desa memenuhi syarat 1 sampai syarat 3 yaitu 1) Keunikan dan keaslian, 2) Letak dan aksesibilitas, 3) Budaya yang mencakup adat istiadat dan pelaku adat lokal serta norma setempat dan 5) Alam. Ini artinya sebagaian besar desa di Jerowaru itu memiliki daya tarik wisata yang memungkinkan untuk dikembang-kan.

Fenomena yang didapat dari hasil identifikasi adalah Desa Kwang Rundun. Desa ini merupakan desa yang memenuhi syarat desa wisata dari mulai syarat nomor 1 Keunikan dan keaslian sampai syarat nomor 5 yaitu Alam. Namun desa ini belum mampu memenuhi syarat nomor 6 Partisipasi masyarakat lokal dan syarat nomor 7 yakni Terjaminnya keamanan, ketertiban, dan kebersihan.

Fenomena lain adalah Desa
Pemongkong. Desa ini memenuhi berbagai syarat kecuali syarat nomor 4 yaitu sarana wisata dan syarat nomor 7 yaitu jaminan kemanan dan kebersihan. Dalam sejarahnya Desa Pemongkong adalah desa induk dari Desa Ekas Buana dan Desa Kwang Rundun. Desa Ekas Buana dan Desa Kwang Rundung didirikan berdasarkan Peraturan Daerah Kabupaten Lombok Timur Nomor 7 Tahun 2011. Setelah pemekaran, Desa Pemongkong kehilangan fasilitas wisata yang dulu dimiliki.

Analisis terhadap kebijakan pemerintah daerah baik Pemerintah Provinsi NTB maupun Pemerintah Kabupaten Lombok Timur menunjukan pengembangan desa wisata berfokus pada beberapa desa dengan kategori yang telah ditetapkan oleh Pemerintah Provinsi.

Yang masih menjadi permasalahan di desa wisata di Kecamatan Jerowaru adalah terbatasnya akomodasi. Tercatat hanya dua desa yang memiliki akomodasi Hotel. Desa-desa tersebut adalah Desa Sekaroh dan Desa Ekas Buana. Hal ini berbeda dengan beberapa desa wisata potensial di Kecamatan Sikur dan Kecamatan Sembalun. Di kedua kecamatan tersebut terdapat banyak homestay sebagai pilihan wisatawan selain hotel.

Meskipun kekurangan akomodasi dan letaknya yang relatif jauh, desa wisata di Jerowaru cukup mudah untuk diakses dengan kendaraan. Dukungan infrastruktur di Jerowaru saat ini memungkin untuk mengakses desa-desa di kecamatan itu dengan mudah baik dari ibu kota provinsi, ibu kota kabupaten atau dari Lombok International Airport. Hanya di beberapa objek wisata pantai seperti Pantai Pink, akses jalan masih belum memenuhi syarat.

Selain itu yang juga menjadi permasalahan adalah belum terpenuhinya syarat ke tujuh Terjaminnya keamanan, ketertiban, dan kebersihan. Hampir semua desa potensial wisata di Jerowaru Lombok 
Timur saat ini kotor oleh sampah baik sampah dari masyarakat setempat maupun wisatawan. Hal ini tidak bisa dipungkiri mengingat desa wisata di Lombok Timur tidak dipersiapkan dari sisi kebersihannya sehingga tidak memiliki fasilitas pengelolaan sampah. Sementara masalah keamanan selalu menjadi kendala mengingat tingginya kriminalitas seperti pencurian dengan kekerasan di wilayah selatan Lombok Timur tersebut

\section{Kesimpulan dan Saran \\ Kesimpulan}

Potensi pengembangan Desa Wisata di Kecamatan Jerowaru Kabupaten Lombok Timur tersebar di setiap sudut kecamatan tersebut. Identifikasi me-nunjukkan ada 6 desa paling me-mungkinkan untuk dikembangkan menjadi desa wisata di kecamatan tersebut.

Menurut tingkat kesiapannya desa wisata potensial di Jerowaru belum ada desa yang masuk dalam kategori Desa Wisata Paripurna. Artinya desa-desa di Jerowaru belum mampu memenuhi seluruh syarat desa wisata. Meskipun demikian beberapa desa potensial seperti Desa Ekas Buana dan Desa Sekaroh sudah mampu masuk kategori Desa Wisata Permulaan. Sementara itu desa-desa lainnya masih masuk dalam kategori Rintisan Desa Wisata. Desa-desa tersebut adalah Kwang Rundun, Batu Nampar, Seriwe dan Pemongkong.

Sementara itu Faktor internal yang mendukung pengembangan Desa Wisata di Kecamatan Jerowaru Kabupaten Lombok Timur adalah Alam, Sosial Budaya, Akomodasi, Lokasi objek wisata yang berdekatan dan Setiap desa memiliki objek wisata

\section{Saran}

Untuk Pemerintah sebaiknya berupaya meningkatkan keamanan di wilayah Jerowaru sehingga aman dikunjungi wi- satawan dan meningkatkan citra Jerowaru sebagai wilayah yang potensial untuk menjadi objek wisata dunia.

Pemerintah Lombok Timur sebaiknya membuat kebijakan dan peraturan yang fokus pada pariwisata yaitu untuk mempertahankan objek wisata di pedesaan, aturan yang mempermudah pendirian homestay serta aturan dan manajemen persampahan di desa wisata potensial

Selain itu dibutuhkan Program Peningkatkan kapasitas desa di Jerowarou sehingga betul-betul mampu menjadi desa wisata dengan mendorong masyarakat untuk sadar wisata sehingga berpartisipasi secara aktif dalam pariwisata.

Untuk Pengusaha sebaiknya segera memanfaatkan peluang untuk membuat usaha wisata di Jerowaru terutama usaha akomodasi. Ini mengingat kurangnya fasilitias akomodasi di daerah wisata itu.

Untuk Masyarakat Desa Wisata Potensial di Jerowaru sebaiknya aktif dalam pariwisata dengan pertama memelihara desa dan pantai sehingga lestari potensi wisatanya baik dari sisi alam maupun sosial budaya dan kedua, memanfaatkan peluang mengembangan usaha wisata rumahan seperti membangun homestay, warung, art shop dan kebun buah.

\section{Daftar Pustaka}

Anonim. (2017, December 11). Gili Sunut dan Keindahan Alamnya. Mataram. Retrieved from http://www.suarantb.com/news/201 7/12/11/249868/Gili.Sunut.dan.Keinda han.Alamnya

Anonim. (2017, February 6). Desa Wisata. republika.co.id

Dharmawan, I M. A., Sarjana, I M, \& Yudhari, I D. A. S. (2014). Strategi Pengembangan Desa Wisata Di Desa Belimbing Kecamatan Pupuan Kabupaten Tabanan. E-Jurnal Agribisnis dan Agrowisata, 3(1). 
Erwin, o. L. T. (2012). Desa wisata kawasan Borobudur: Tersembunyi di 20 desa wisata : Wisata alam, agrowisata, kuliner, kerajinan, tradisi \& homestay : 145 destinasi wisata. Jakarta: Gramedia Pustaka Utama.

Gunardi, G. (2010). Identifikasi Potensi Kawasan Wisata Kali Pasir, Kota Tangerang. Jurnal PLANESA TM, 1(1).

Ismayanti. (2010). Pengantar Pariwisata. Jakarta: Grasindo.

Kotler, P., \& Armstrong, G. (2014). Principles of Marketing (13th ed.). Pearson Education, Inc.

Lutpi, H. (2016). Analisis Tingkat Partisipasi Masyarakat Dalam Pengembangan Pariwisata Pantai Di Kecamatan Jerowaru. Jurnal Program Studi Pendidikan Ekonomi, 8(3).

Murdi, L. (2012, April 1). Sistem Kekerabatan Masyarakat Desa Jerowaru: Sebuah Kajian Sejarah Sosial. Retrieved from http://murdilalu.wordpress.com/2012 /04/01/sistem-kekerabatanmasyarakat-desa-jerowaru-sebuahkajian-sejarah-sosial-2/

Murdi, L. (2012, March 31). Banjar Sebagai Solidaritas Sosial Masyarakat (Kajian Pendahuluan Fungsi Banjar Pada Masyarakat Pedesaan di Kecamatan Jerowaru. Retrieved from http://murdilalu.wordpress.com/2012/03/ 31/banjar-sebagai-solidaritas-sosialmasyarakat-kajian-pendahuluan-fungsibanjar-pada-masyarakat-pedesaan-dikecamatan-jerowaru/

Nurlaili, W., Cornelia, M, \& Zamron, A. (2014). Potensi Dan Permasalahan Sosial Ekonomi Masyarakat Perikanan Kabupaten Lombok Timur Dalam Mendukung Industrialisasi. Buletn Riset Sosek Kelautan dan Perikanan, 9(2). ejournalbalit-

bang.kkp.go.id/index.php/mra/article/do wnload/429/430.

Oktaryani, G. A., \& Permadi, L. A. (2013, November). Peranan Sektor Pariwisata Terhadap Pertumbuhan Ekonomi Di Provinsi Nusa Tenggara Barat. Pro- siding Seminar Nasional Pariwisata Hijau dan Pengembangan Ekonomi Mataram.

Panca, A. (2017). Pantai Ekas, Surga Alami dan Asri di Lombok Timur. Mataram: penginapan.net. penginapan.net/pantai-ekas-surga-alami-danasri-di-lombok-timur/

Pemkab Lombok Timur. (2017). Peraturan Daerah Kabupaten Lombok Timur Nomor 7 Tahun 2011. Kementerian Dalam Negeri RI. jdih.setjen.kemendagri.go.id/files/KA B_LOTIM_7_2011.pdf

Permadi, L. A. (2008). Faktor-Faktor Yang Mempengaruhi Konsumen Dari Etnis Sasak Untuk Membeli Produk Tradisional Di Lombok Tengah. Jurnal Riset Manajemen, 8(2).

Permadi, L. A., Asmony, T., Widiana, H., \& Hilmiati. (2017). Laporan Penelitian Studi Potensi Pengembangan Desa Wisat. Mataram: BP2EB FEB Unram.

Rijal. (2017, May 30). Pantai Pink Lombok Timur Dan 5 Tempat Wisatanya. Retrieved from http://www.dilombok.com/pantaipink-lombok/77/

Sastrayuda, G. S. (2010). Hand Out Mata Kuliah Concept Resort And Leisure, Strategi Pengembangan Dan Pengelolaan Resort And Leisure. UPI Bandung. Retrieved from http://file.upi.edu/Direktori/FPIPS/LAI NNYA/...S/.../sejarah resort.pdf

Sugiyono. (2011). Metode Penelitian Kuantitatif Kualitatif dan R\&D. Bandung: CV Alfabeta.

Suntalangu, D., \& Sekretaris. (2015, August 14). Wisata Lobster di Pantai Batu Nampar. Desa Suntalangu. Retrieved from http://berugaqelen2010.wordpress.c om/2015/08/14/wisata-lobster-dipantai-batu-nampar/

Syarief, F. (2014, December 20). 20 Tempattempat Wisata Pesona Alam Lombok 
Timur. Explore Lombok. lomboknesia.blogspot.co.id/2014/12/20tempat-tempat-wisata-pesonaalam.html

Tim Penyusun Buku Nusa Tenggara Barat Dalam Data Tahun 2015. (2016). Nusa Tenggara Barat Dalam Data Tahun 2015. Mataram: BAPPEDA Prov NTB dan BPS Prov NTB. bappeda.ntbprov.go.id/wpcontent/uploads/2015/12/DDD_201510112015-final-OK..pdf
Wilson, E., \& Hollinshead, K. (2015). Qualitative tourism research: Opportunities in the emergent soft sciences [Regular]. Annals of Tourism Research, 54, 30-47. doi:10.1016/j.annals.2015.06.001

Zakaria, F., \& Suprihardjo, R. D. (2014). Konsep Pengembangan Kawasan Desa Wisata di Desa Bandungan Kecamatan Pakong Kabupaten Pamekasan. Jurnal Teknik Pomits, 3(2). 